\title{
Electronic Cases as An Element of the Administrative Procedure in The Provision of Administrative Services
}

\author{
Oleg Dubinskiy ${ }^{1}$, Olena Lomakina ${ }^{1}$, Oleksandr Sikorskyi ${ }^{1 *}$, and Azamat Kudaibergenov ${ }^{2}$ \\ ${ }^{1}$ Admiral Makarov National University of Shipbuilding, 54025, Ukraine \\ ${ }^{2}$ Karakalpak State University named after Berdakh, 230112, Republic of Karakalpakstan, Uzbekistan
}

\begin{abstract}
The article is devoted to the study of the current state of legal regulation of the institute of electronic case as an element of administrative procedure in Ukraine and the practice of its implementation on the example of the procedure for providing administrative services through the Centers of administrative services. The main problems of the institute and possible ways to solve them are considered, as well as prospects for the development of administrative procedure, based on international experience and regulatory framework of states, including - members of the European Union in the study area.
\end{abstract}

\section{Introduction}

After gaining independence, Ukraine took the direction of updating the legislative basis in all branches of law, streamlining all spheres of society. The globalization processes, which caused rapid changes in the protection of the legal rights, freedoms and interests of the citizen, influenced the formation of the mechanism of the system of administrative services. With the beginning of the administrative reform in our state, the issues of improving the quality of the provision of administrative services, which are provided by public authorities and local governments, are becoming increasingly important.

Despite many fundamental studies on the subject, questions about the definition of public services and questions about procedure of administrative services still remain quite controversial and therefore require a deeper analysis, the study of the specific features and improvement of not only theoretical basis, but also the consolidation of research data on legislative level.

The problems of the study of administrative services, their legal regulation and ways of improvement were analyzed and studied in their works by such scientists as: Andrushko P.P., I.V. Boyko, A.T. Zima, Glushkov V., Evtikheev I.I., Lazarev B.M., Kruglikov L.L., Korzhansky M.I., Melnik M.I., V.P. Timoshchuk, Khavronyuk M.I., Galakhova A.V. and others.

However, given the realities of the ever-growing role of information telecommunication technologies in state and municipal administration, informatization of society at all levels and the peculiarities of the functioning of our state in conditions of quarantine, the issue of implementing electronic government in the provision of administrative services seems to be relevant. Indeed, it is the in-depth and systematic implementation of the latter that will fully ensure the implementation of the concept of state policy for improving the quality and availability of administrative

*Corresponding author: alex.nic.gm@gmail.com services, transparency, efficiency and openness of the activities of the subjects of their provision.

So, according to the information posted on the official website of the Cabinet of Ministers of Ukraine, the most important area in the field of electronic governance is electronic services. Currently, the Government Portal, which serves as a "one-stop shop" for all online services, already has 118 e-services. Among them are such socially important ones as the registration of a childbirth allowance, business registration services, services in the land and construction sectors. Also, important sets of electronic services for drivers and carriers were launched, available respectively in the carrier's and driver's electronic cabinets. It is summarized, that only in 2018, the level of use of electronic services in Ukraine has tripled [1] and continues to grow in the future, given the increase in the categories of people using information and communication technologies in everyday life and business.

However, some problematic issues of the introduction of e-government in the provision of administrative services were covered in the works of the mentioned scientists fragmentarily, within the framework of a more general issue. In particular, in this direction special attention should be paid to the formation of an electronic case at the time of provision of administrative services, because the case is a key element of the administrative procedure at all stages, which, given the above, determines the relevance of this study.

\section{Main part}

\subsection{Legal regulation of e-government and provision of e-services in Ukraine}

It is worth noting that the legal prerequisites for the introduction of electronic government and the provision of electronic services by public authorities in Ukraine are due to the adoption of the Laws of Ukraine 
"On electronic documents and electronic document management" dated May 22, 2003 No. 851-IV and "On electronic digital signature" dated 22 May 2003 No. 852-IV.

Developing the provisions of these laws, taking into account domestic experience in this area, in 2016 formed the Concept for the development of electronic services in Ukraine, approved by the Order of the Cabinet of Ministers of Ukraine dated November 16, 2016 № 918-r. In the provisions of this concept, the electronic service is defined as an administrative and other public service provided to the subject of circulation in electronic form by means of information, telecommunications, information and telecommunications systems. The text of the document also stipulates that reducing the number of documents required from the subject of application through the introduction of interdepartmental electronic interaction, opening access to state information resources and introduction of electronic forms of interaction between subjects and subjects of administrative services are the main ways and means of solving problems, related to the development of the electronic services system in Ukraine [2].

The next stage of improving Ukrainian legislation in 2017 was the adoption of the Law of Ukraine "On electronic trust services" from 05.10.2017 № 2155VIII, settled relations in the provision of electronic trust services of electronic identification [3] and approval by the Order of the Cabinet of Ministers of Ukraine from 20 September 2017 № 649-r of the Concept of e-government development in Ukraine (hereinafter - the Concept) [4].

According to the Concept, e-government is a form of organization of public administration, contributes to increasing the efficiency, openness and transparency of the activities of state authorities and local governments using information and telecommunication technologies to form a new type of state focused on meeting the needs of citizens [4].

Taking into account the advantages of e-services technologies, the main measures to ensure the development of e-government in Ukraine in the direction of modernizing public services and developing interaction between government, citizens and business using information and communication technologies are:

- the introduction of electronic services, including administrative ones, in all spheres of public life, as well as the provision of integrated electronic services for life and business situations;

- implementation of the one-stop-shop principle by ensuring the development and functioning of the Unified State Portal of Administrative Services as a single point of access for individuals and legal entities to electronic services;

- development of electronic public procurement, electronic contracts and invoices, electronic auctions;

- encouraging the use of electronic services by individuals and legal entities [4].

The implementation of the provisions of the Law of Ukraine "On electronic trust services" took place by introducing the Resolution of the Cabinet of Ministers of June 19, 2019 № 546 in Ukraine functioning of the electronic identification system [5], which fully implements the idea of remote provision of administrative services in electronic form.

Further development in the field of "digitalization" of administrative services in Ukraine is the introduction of the Resolution of the Cabinet of Ministers of Ukraine "Issues of the Unified State Web Portal of Electronic Services of the Unified State Portal of Administrative Services" from December 04, 2019 № 1137 Portal "Action" - as a service by means of which the idea of "the country in the smartphone" is introduced. The provision also stipulated that from January 1, 2020, the Unified State Web Portal of Electronic Services will also perform the functions of the Unified State Portal of Administrative Services [6].

It should also be added that in accordance with the Law of Ukraine "On Amendments to Certain Legislative Acts of Ukraine Concerning Optimization of the Network and Functioning of Administrative Service Centers and Improvement of Access to Administrative Services Provided in Electronic Form" of Novrmber 03, 2020 №943-IX Unified the state portal of administrative services has been liquidated as such, which does not meet today's requirements. Information to it is mainly entered manually. The portal has an outdated interface and software, which makes it impossible to implement modern services (such as using the portal via a smartphone). In addition, it provides only administrative services, which are only part of other electronic public services, and therefore has become an extra link between the applicant and the Unified State Web Portal of electronic services [7].

Also, among the important innovations of the law were: the elimination of Administrative Services Center formed by district state administrations and the provision of services only in the Administrative Services Center of local governments; provision of services not through the Administrative Services Center, but in the Administrative Services Center (that is, administrative services will be provided by representatives of the subjects of administrative services located in the Administrative Services Center, administrators or through administrators through their interaction with the subjects of administrative services).

A certain step towards the introduction of the obligation to conduct electronic cases during the provision of administrative services was taken with the adoption of the Resolution of the Cabinet of Ministers of October 28, 2020 No. 1035. Thus, the Resolution provides that from March 1, 2021 applications for administrative services on certain social issues are accepted by officials of the executive body or the center for the provision of administrative services exclusively with the formation of the electronic case [8].

\subsection{Analysis of the current state of implementation of electronic cases as an element of administrative procedure}


Taking into account the fact that the formation of a case during the provision of administrative services, including electronic, is inextricably linked with the procedure for their provision and that there is no separate legislation that would define the procedure for such provision in a systematic form, it is advisable to consider the issue under study through the prism current legislation on administrative services.

In national legislation, the issue of regulating the administrative procedure is also assigned a significant role.

This issue becomes especially relevant in the context of a comprehensive reform of the system of public administration and local self-government.

One of the examples of the regulation of the basic principles of administrative procedure at the level of the law is now two drafts of Law of Ukraine "On Administrative Procedure" dated 09.06.2015 [9], however, it never came into force. In 2020, the draft of law "On Administrative Procedure" was finalized, developed by the Ministry of Justice of Ukraine and approved by the Cabinet of Ministers of Ukraine. From the moment of its registration by the Verkhovna Rada of Ukraine dated May 14, 2020 under number 3475, the process of passing the legislative procedure of this bill began [10].

In our opinion, the basic category of "administrative procedure" is a problematic or insufficiently resolved issue in these draft laws. Although the very concept of "administrative procedure" of the 2020 draft law duplicates the definition of the 2015 draft law, that is, it discloses the procedure through the concept of administrative proceedings (Paragraph 4,5, Part 1, Article 2 of the draft Law). There were also attempts to codify administrative and procedural activities in Ukraine, while forming unified principles for the activities of officials of public authorities.

Analyzing the provisions of the Law of Ukraine "On Administrative Services", we determine that it contains an article, dedicated to the order of the provision of administrative services, but does not contain a clear set of actions of subjects of legal relations in the field of administrative services.

The draft of Administrative Procedural Code of Ukraine on December 3, 2012 also contains the definition of "administrative procedure", which is the procedure for administrative proceedings determined by legislation [11]. Such a definition is not advisable, since it does not reflect the main features of the concept at all and leads to a misunderstanding and interpretation of this term.

An interesting idea is represent by V.P. Timoshchuk, who notes that the administrative procedure is the procedure established by the current legislation for the consideration and resolution of individual administrative cases by administrative bodies [12, p.24].

A.S. Lagoda details the concept and defines the administrative procedure as the procedure established by law for the consideration and resolution of individual cases by executive authorities and local selfgovernment bodies, the ultimate goal is the adoption of an administrative act or the conclusion of an administrative contract [13, p.4].

Electronic services are generally a novelty for Ukrainian legislation and the definition of the administrative procedure for the provision of electronic services is not disclosed at all. So, most scientists consider the administrative procedure for the provision of electronic services as a set of sequential actions associated with the implementation of assigned tasks and powers to provide electronic services, which are performed using information and communication technologies by the relevant official in accordance with the current legislation [14, p.124].

The current legislation, namely the Law of Ukraine "On Administrative Services" contains the term "procedure" in Paragraph 8 of Part 1 of Art. 4 and Part 5 of Art. 8 of this Law. Thus, Paragraph 8 of Part 1 of Article 4 contains the principle of rational minimization of the number of documents and procedural actions, on which the state policy in the provision of administrative services is based [15, p.8, p. 1 of Art.4]. This principle implies a reduction in the number of documents and actions that are required to provide a public service and aims to simplify the procedure for obtaining administrative services.

In turn, in Part 5 of Art. 8 indicates that the technological map of the public service contains information on the procedure for the provision of public services, namely:

1) the stages of processing an application for the provision of a public service;

2) the responsible official;

3) structural units responsible for stages (action solutions);

4) the timing of the stages (actions, decisions ) [15, p.5 of Art.8]. This norm implies elements of streamlining the procedure for the provision of public services.

It follows from this that the technological map of an administrative service is a list of elements of the improvement of the procedure for the provision of public services.

The Resolution of the Cabinet of Ministers of Ukraine dated January 30, 2013 No. 44 "On approval of the requirements for the preparation of a technological card of public services" contains the stages of providing administrative services, which can be considered stages of an administrative procedure, because each stage includes the procedure for performing actions when solving an administrative case [16]. It follows from this that the structure of a procedure is made up of stages, and stages are an element of stages.

Moreover, it is worth noting that Paragraph 6 of this Resolution states that the stages of processing an application for the provision of a public service include:

1) registration (execution) of the appeal of the subject of circulation;

2) development of an appeal and registration (approval) of the result of the provision of public services by structural divisions and officials of the 
subject of the provision of administrative services, in particular, through interaction of structural divisions of the subject of providing administrative services, the subject of providing administrative services with other bodies to obtain documents, information, decisions, answers required for the provision of public services, as well as with administrators - when providing public services through the center for the provision of administrative services, indicating the deadlines for such actions;

3) the issuance of the result of the provision of public services and its registration [16].

In turn, A. N. Bukhanevich notes that such a mechanism is not acceptable, and even goes beyond the procedure for providing administrative services [17, p.129].

V.P. Tymoshchuk, noting that such information should not be contained in the technological map, since the latter is not intended for subjects of circulation. Filing a complaint represents the beginning of new stages in the course of the case; therefore, it should only be briefly said about the mechanism for appealing the result of the provision of the public service $[18$, p.139].

Thus, we can say that the procedure for the provision of public services conditionally includes three stages, which are divided into the appropriate stages: registration of the appeal, consideration of the appeal and issuing a response to the appeal. Moreover, the formation of the case is carried out already at the initial stage of the administrative procedure.

It should also be added that in accordance with Part 1 of Article 9 of the Law of Ukraine "On Administrative Services", administrative services are provided by the subjects of the provision of administrative services directly through the centers for the provision of administrative services and / or through the Unified State Portal of Administrative Services [15, p.1 of Art.9].

Thus, when applying for an administrative service to the Center for administrative services, the first stage of the procedure for providing such a service will contain the stages that are determined in the Model Regulations of the Center for administrative services. Thus, registering the application, the administrator: checks the compliance of the incoming package of documents with the information card of the public service, if necessary, assists the subject of the application in filling out the application form; compiles a description of the incoming package of documents; registers the incoming package of documents by entering data into the registration log (in paper and / or electronic form); draws up a letter on the progress of the case in paper and / or electronic form; finds out the subject of providing administrative services, which is competent to decide on the case; sends the incoming package of documents to the subject of administrative service [19]. So, we can conclude, that the form of the case for the provided administrative services is determined individually.

At the same time, the organizational and legal basis of electronic document management is established by the Law of Ukraine "On electronic documents and electronic document management" dated May 22, 2003 No. 851-IV.

According to Article 10 , the sending and transmission of electronic documents are performed by the author or intermediary in electronic form by means of information, telecommunications, information and telecommunications systems or by sending electronic media on which this document is recorded [20].

The law also provides for the procedure for obtaining electronic documents. Thus, an electronic document is considered to be received by the addressee from the time the author receives a message in electronic form from the addressee on receipt of this electronic document by the author, unless otherwise provided by law or prior agreement between the subjects of electronic document management [20].

If a preliminary agreement between the subjects of electronic document circulation does not determine the procedure for confirming the fact of receipt of an electronic document, such confirmation can be carried out in any order by automated or otherwise in electronic form or in the form of a document on paper. The specified confirmation must contain data on the fact and time of receipt of the electronic document and on the sender of this confirmation [20].

If the author does not receive confirmation of the fact of receipt of this electronic document, it is considered that the electronic document has not been received by the addressee [20].

Unless the author and the addressee have previously agreed otherwise in writing, the electronic document is considered to be sent by the author and received by the addressee at their location (for individuals - place of residence), including if the information, telecommunications, information and telecommunications system with which the the document is located elsewhere. The location (residence) of the parties is determined in accordance with the law [20].

The second stage of the procedure for providing public services covers not one but several stages with different performers and is quite extensive and contains a large number of procedural points. Thus, in paragraph 6 of the Resolution of the Cabinet of Ministers of Ukraine of January 30, 2013 No. 44 "On approval of the requirements for the preparation of technological card of public service", it is noted that the stages of processing the application for public service are determined in accordance with regulations establishing the procedure public service and unless otherwise specified by law [16]. This indicates that there are cases when certain types of administrative services provide for a different number of stages at this stage, so it is necessary to consolidate this procedure in the relevant legislation.

The third stage of the procedure for the provision of public services includes the following stages:

1) the subject of providing administrative services: forms the output package of documents; transfers it to the Center for administrative services; notes this in the case letter; 
2) the administrator of the center: informs about the result of providing the state service to the subject of the address in the way specified in the description of the incoming package of documents; registers the outgoing package of documents by entering the relevant information in the letter of the case, as well as in the relevant register in paper and / or electronic form; transfers the original package of documents to the subject of application in person against a receipt (including his authorized representative) upon presentation of an identity document and / or certifying his authority, or in cases provided by law, is transferred by other acceptable to the subject of application [19].

Since the electronic provision of services is introduced, it would be appropriate at this stage to provide the possibility for a person to pay the funds needed to receive the service in electronic form.

In addition, the process of providing electronic services should include a stage of appeal against the actions or inaction of the authority that provided the service. The implementation of a person's appeal of actions or inaction of a public administration body, for example, administratively, should also take place electronically with the possibility of filing an electronic complaint and monitoring the results of such a complaint [14, p.127].

There is a certain problem of providing administrative services to determine the subject composition of the relevant legal relations, as there is a question of determining the range of subjects of administrative services, the competence of these subjects and the range of powers, in turn reflected in the order of cases.

The Law of Ukraine "On Administrative Services" defines the subjects of administrative services - the executive body, another state body, the authority of the Autonomous Republic of Crimea, local government, their officials, state registrar, the subject of state registration, authorized in accordance with the law to provide administrative services [15]. At the same time, their powers in a systematized form are absent and prescribed for each of them separately in their own normative legal acts, which in their number constitute a very large accumulation of regulatory and legal information, which leads to misinterpretation and application and creates conflicts. Moreover, today, the number of entities providing administrative services is quite large, and this leads to difficulties for the relevant entities applying for a certain public service.

Some administrative scientists believe that this composition of the subjects of administrative services is narrow and does not contain a complete list of subjects of administrative services. Moreover, the Concept for the Development of the System for the Provision of Administrative Services by the Executive Authorities, approved by the order of the Cabinet of Ministers of Ukraine dated February 15, 2006 No. 90-r, provided for the presence of state enterprises, institutions and organizations among the subjects of administrative services, who are not subjects of power [21].
I.B. Koliushko also expresses his opinion on this issue, noting that the circle of subjects of providing administrative services is limited only by executive authorities and local governments and instead of including enterprises and institutions in the circle of subjects of providing administrative services, they were simply removed from the list of subjects of providing administrative services, which leads to the spread of bureaucracy [18, p.9].

Even despite the presence of certain information on the Internet, it is not always easy to find information about whether the subject provides a certain administrative service and indeed it is this subject for the provision of administrative services that is endowed with appropriate powers and does not duplicate the activities of other subjects of public administration and the like.

\subsection{International experience in implementing electronic cases as an element of administrative procedure}

Scientist Yu.M. Zhuk notes that today there is an urgent need to introduce foreign experience in the provision of administrative services, which should be used to improve the existing Ukrainian model and bring it in line with European standards [22, p.59]. In particular, most administrative scientists are inclined to believe that there is a need to put into practice a real dialogue between Ukraine and a number of European countries to implement and study in practice the experience of providing services, rather than formally copying one or another element of the system.

From the point of view of the functioning of the system for the provision of administrative services in electronic form, Poland has an interesting experience. In this country, a centralized system of Resident Service Departments (WOM) has been established, which is a guarantee of proper quality of services and speeding up administrative procedures [22, p.63].

A special feature is the eWOM Internet resource, which contains document forms for accessing any of the 18 local departments in the districts. Moreover, the site contains extended information about: precinct departments, customer service standards, the page of the citywide Citizen Service Center, regulatory framework, means of communication with other institutions and the like. At the same time, there is a special page "Alphabetical list of cases", which provides information on 268 administrative cases and services.

For each service there is detailed information: card number (application form to be filled in); documents required for submission; the place of filing documents and obtaining a decision on the case, the procedure for payment for services, the deadline for providing consumers with a response, etc. [23, p.80].

The structure of the WOM also includes: points of consideration of appeals of consumers and provision to them of administrative services on administrative questions, cash desks for payment of administrative services, information points, points of insurance, 
provision of photocopying services and photo services [23, p.80].

In the process of solving the case and receiving public services in the Department, the person carries out the appropriate list of actions. In particular:

- receives a form of the document on the case in the Information point of the department or on electronic resources;

- fills in the form of the document on the case in the Information point of the department or on electronic resources;

- attaches to the form the documents on the case in the information point of the Department or on electronic resources the necessary documents that are required;

- receives a receipt for the service, pays at the box office in cash, by card, or by transferring funds to the specified account [23, p.81].

Canada's experience in providing administrative services is also quite useful. First of all, it should be noted that Canada has three clearly separated levels of government: federal, provincial, and municipal. Thus, the largest number of services is provided at the provincial level.

Also in Canada, the term "administrative services" is not used, but the term "public services" ("government services") is used. They are divided into "internal" (government for government) and "external" (for citizens, business). These services include regulatory measures and information services [24].

The most common service integration in Canada is database integration. A novelty is the consideration of comfort for the consumer of the service, because if it is possible to submit an application or receive services via the Internet or by telephone, then this method of receiving or providing the service is available.

In Canada, special attention is now paid to five channels for applying for services: telephone, personal visit, autonomous interactive service centers, Internet, mobile communications. Moreover, mobile (outbound) offices are being introduced in Canada [24].

The creation of a single digital market for public services is a modern direction of reforming the provision of electronic services in the EU countries. It should be noted that the market of electronic public services in the countries of the European Union is acquiring a rapid pace of development, and the necessary task today is to ensure compatibility between the systems for the provision of electronic public services of various EU member states [25, p.101].

The provision of cross-border administrative services in the EU countries is stipulated by the Regulation of the European Parliament and of the Council "On electronic identification and trust services for electronic transactions in the internal market and repealing Directive 1999/93 / EU" dated 23 July 2014 No. 910/2014, Decision of the European Parliament and Council "On the creation of a program of compatibility of solutions and a common framework for European public administrations, enterprises and citizens (ISA2 program) as a tool for modernizing the public sector" dated November 25, 2015 No. (EU) 2015/2240 and the like.

To meet the requirements of these regulations in the EU introduced the program "STORK", which "based on ID technology is available in each country and provides systematization of data on common technical and legal schemes, provides understanding between users with each other" [26, p.15].

In addition, in order to provide cross-border electronic services in the EU, there is an electronic service "SPOCS (Simple Procedures Online for CrossBorder Services)", which provides simple online procedures for cross-border services, electronic portal e-CODEX (e-Justice Communication via Online Data Exchange)", created to provide electronic interaction in the field of justice through online data exchange, as well as the program "epSOS", which provides access to cross-border health services, and the electronic service "PEPPOL (Pan-European Public Procurement) Online)", introduced for the purpose of online access to public procurement. The current state of cross-border service provision by administrative bodies in the EU is characterized by the integration of separate electronic services to provide these services into a single web portal, the functions of which will provide a wide range of public services in electronic form throughout the EU. In particular, the portal "e-SENS (Electronic Simple European Networked Services)" is currently being developed, combining the functions of the above-mentioned electronic services and formed to provide cross-border public services in electronic form using common and reusable technical components" [27, p.1].

\section{Conclusion}

After analyzing the above material, we can identify the following problems associated with the formation of electronic cases:

- the lack of systematic legislation on the procedure for providing administrative services, and therefore the order of formation of cases, including electronic;

- the question of determining the range of subjects of administrative services, the competence of these subjects and the availability of a range of powers, in turn, is reflected in the order of formation of cases;

- insufficient implementation of information systems in the implementation of electronic document management and their departmental branching, because for most subjects of power e-government is understood only as the informatization of certain documents.

Most of these problems can be solved by adopting the Administrative Procedure Code of Ukraine, which should include current scientific works and take into account aspects of modern knowledge about man, society and the state, the foundation and patterns of their development, as well as the interaction of the subject of administrative services with a person, because all the sphere of rendering of administrative services is directed on realization of the rights and freedoms of the last. 
It would be expedient to provide in such an act the obligation to keep an electronic form of record keeping during the provision of administrative services and to introduce sufficient technical support for this process. In addition, the conceptual apparatus of the draft Law of Ukraine "On Administrative Procedure" dated May 14, 2020 under number 3475, namely, "administrative procedure", requires improvement, because in our opinion the understanding of the legislator of this category has not changed in all similar bills since the first bills. National scientists have developed a number of alternative interpretations of the concept of "administrative procedure", which are more in line with the modern paradigm.

At the same time, we should not forget about the "human" factor, to overcome which it is necessary to carry out proper selection of personnel and constantly improve their professional level.

\section{References}

1. E-government is the key to reforms in Ukraine. Government portal website. URL: https:/www.kmu.gov.ua (access date 28.01.2021)

2. On approval of the Concept for the development of the electronic services system in Ukraine: Order of the Cabinet of Ministers of Ukraine dated November 16, 2016 No. 918-r. URL: https://zakon.rada.gov.ua (date of access 28.01.2021)

3. On electronic trust services: Law of Ukraine dated 05.10.2017 No. 2155-VIII. URL:

https://zakon.rada.gov.ua (date of access 28.01.2021)

4. On approval of the Concept of Development of Electronic Governance in Ukraine: Order of the Cabinet of Ministers of 20.09.2017 No. 649-r. URL: https://zakon.rada.gov.ua (access date 28.01.2021)

5. On approval of the Regulation on the Integrated Electronic Identification System: Resolution of the Cabinet of Ministers dated June 19, 2019 No. 546. URL: https://zakon.rada.gov.ua (date of treatment 01.28.2021)

6. The issue of the Unified State Web Portal of Electronic Services of the Unified State Portal of Administrative Services: Resolution of the Cabinet of Ministers of Ukraine dated 04.12.2019 No. 1137. URL: https://zakon.rada.gov.ua (date of access 28.01.2021)

7. On amendments to some legislative acts of Ukraine regarding optimization of the network and functioning of centers for the provision of administrative services and improvement of access to administrative services that are provided in electronic form: Law of Ukraine dated 03.11.2020 No. 943-IX. URL: https://zakon.rada.gov.ua (date of access 28.01.2021)
8. On amendments to some resolutions of the Cabinet of Ministers of Ukraine: Resolution of the Cabinet of Ministers of 28.10.2020 No. 1035. URL: https://zakon.rada.gov.ua (access date 28.01.2021)

9. On the administrative procedure: the draft Law of Ukraine of 09.06.2015. Ips.ligazakon: website. URL: https://ips.ligazakon.net (access date 28.01.2021)

10. On the administrative procedure: the draft Law of Ukraine of 14.05.2020 No. 3475. VRU: website. URL: https://zakon.rada.gov.ua (access date 28.01.2021)

11. Draft of Administrative Procedure Code of Ukraine. VRU: website. URL: https://zakon.rada.gov.ua (access date 28.01.2021)

12. V. Timoshuk Administrative procedure and administrative services. Foreign experience and proposals for Ukraine, P. 24 (2003)

13. A. Lagoda Administrative procedure: theory and practice of application, P. 4 (2007)

14. I. Tishchenkova Forum of Law, Administrative procedures for the provision of electronic services by public administration in Ukraine, No. 2, pp. 124-129 (2017) URL: http://nbuv.gov.ua (accessed 28.01.2021)

15. On administrative services: Law of Ukraine of 06.09.2012 No. 5203-VI. URL: https://zakon.rada.gov.ua (access date 28.01.2021)

16. On approval of the requirements for the preparation of the technological card of public services: Resolution of the Cabinet of Ministers of Ukraine of 30.12.2013 No. 44. URL: https://zakon.rada.gov.ua (access date 28.01.2021)

17. A. Bukhanevich Law and Society, The concept and essence of administrative procedure, No. 5, pp. 126-131 (2015)

18. V. Timoshchuk Scientific and practical commentary to the Law of Ukraine "On Administrative Services", P. 9, 139 (2013)

19. On approval of the Model Regulations of the Center for Provision of Administrative Services: Resolution of the Cabinet of Ministers of Ukraine of 1.08.2013 No. 588. URL:

https://zakon.rada.gov.ua (access date 28.01.2021)

20. On electronic documents and electronic document management: Law of Ukraine of 22.05.2003 No. 851-IV. URL: https://zakon.rada.gov.ua (access date 28.01.2021)

21. On approval of the Concept of development of the system of providing administrative services by executive authorities: Resolution of the Cabinet of Ministers of Ukraine of 15.02.2006 No. 90-p. URL: https://zakon.rada.gov.ua (access date 28.01.2021)

22. Yu. Zhuk Efficiency of public administration, Provision of administrative services to the population: foreign aspect, Vol. 1/2 (46/47), pp. 59-69 (2016) 
23. V. Timoshchuk Administrative services; SwissUkrainian project "Support to decentralization in Ukraine - DESPRO", P. 63, 80-81 (2012)

24. V. Timoshchuk Canadian experience in organizing the provision of administrative services. Local Democracy Foundation. Foundation of Local Democracy: website. URL: http://fmd.kh.ua (access date 28.01.2021)

25. Ya. Mikhailyuk, A. Pukhtetska Administrative services in the countries of the European Union and Ukraine: comparative legal aspect, P. 101 (2016)

26. STORK: making life easier, public services more secure // Research * Eu Focus Magazine, No. 12, P. 14-16 (2012)

27. E-SENS: easy digital public services within Europe. e-SENS: website. URL: https: // www.esens.eu (accessed 28.01.2021) 